\begin{tabular}{c}
\hline OPEN \\
JOURNAL \\
SYSTEMS \\
\hline \hline
\end{tabular}

ISSN:2237-2202
Available on line at Directory of Open Access Journals

Journal of Hyperspectral Remote Sensing v.9, n.4 (2019) 166-176

www.periodicos.ufpe.br/revistas/jhrs
Journal of

Hyperspectral

Remote Sensing

\title{
Quantification Caatinga vegetable coverage and water availability by remote sensing in the Brazilian semiarid
}

\author{
Jhon Lennon B. da Silva ${ }^{*}$, Alan C. Bezerra ${ }^{* *}$, Tecla T. F. da Silva ${ }^{* * *}$, Pedro H. D. Batista ${ }^{* * * *}$, \\ Geber B. de A. Moura ${ }^{* * * * * *}$, Pabrício M. O. Lopes ${ }^{* * * * * * *}$ \\ "Master in Agricultural Engineering, Department of Agricultural Engineering, Federal Rural University of Pernambuco \\ (UFRPE), Av. D. Manoel de Medeiros, SN; Dois Irmãos, Recife, Pernambuco, Brazil; CEP: 52171-900. E-mail: \\ jhonlennoigt@ hotmail.com (Corresponding Author) \\ ** Master in Agricultural Engineering, Assistant Professor of Federal Rural University of Pernambuco/Serra Talhada Academic \\ Unit (UAST/UFRPE), Serra Talhada, Pernambuco, Brazil. E-mail: cezaralan.a@ gmail.com \\ ${ }^{* * *}$ Master Student in Agricultural Engineering, Department of Agricultural Engineering, UFRPE. E-mail: \\ teclaticiane12@hotmail.com \\ ****aster in Agricultural Engineering, Ambience Department, UFRPE. E-mail: giga_pedro@ hotmail.com \\ ${ }^{* * * * * *} \mathrm{Ph} . \mathrm{D}$. in Oceanography, Agronomy Department, Full Professor of UFRPE, Recife, Pernambuco, Brazil. E-mail: \\ geber@depa.ufrpe.br \\ Ph.D. in Remote Sensing, Agronomy Department, Assintant Professor of UFRPE, Recife, Pernambuco, Brazil. E-mail: \\ pabriciope@gmail.com
}

Received 21August 2019; accepted 31 October 2019

\begin{abstract}
Brazilian semiarid region is susceptible to drought events, and water scarcity is a frequent problem. Irregularities in rainfall regimes lead to conflicts over water use in these regions, as there is high demand for human consumption and agriculture. Monitoring of the water and natural resources of the semiarid region is essential. Remote sensing, in turn, is effective because it presents high applicability in the heterogeneous mapping of heterogeneous areas in a practical and low cost, both spatially and temporally. Objective was to monitor and quantify the Caatinga vegetation coverage and the water condition by remote sensing through the vegetation index of the normalized water difference. The research was developed in a region of the Brazilian semiarid, municipality of Serra Talhada, Pernambuco, in the period 2015 to 2019. The study was conducted from Landsat satellite images. Thematic maps of the terrestrial surface of the region were developed through the images processing, with application of the Surface Energy Balance Algorithms for Land (SEBAL), performing a spatial-temporal modeling to determine the vegetation index of the standardized modified water difference. The quantification and characterization of Caatinga vegetation and water bodies will be used to compare environmental monitoring studies in the semiarid region and to evaluate environmental impacts. The spatial-temporal monitoring of the vegetation index of the normalized difference of the modified water showed patterns of responses and changes of the Caatinga vegetation coverage, as well as the water availability of the region. Drought favored water scarcity, directly affecting the multiple uses of the semiarid region.

Keywords: water resources, drought events, SEBAL
\end{abstract}

\section{Introduction}

Water is a key factor for human activities and population growth and economic development have increased the demand for this natural resource. Thus, water availability and the risk of supply system failure are major concerns in water resource management systems, especially in semiarid regions (Araújo et al., 2006).

In semiarid there is an irregularity of the rainfall regime, which causes water scarcity and serious conflicts over water use. Thus, a rational and sustainable management is necessary to maintain the quality and quantity of this resource (Medeiros et al., 2016). In aid of this management, it is essential to use tools that allow convenient and accurate monitoring. Geoprocessing in the use of remote sensing techniques using satellite images is an interesting alternative to meet these needs, and the technique has low cost of obtaining it through effective large-scale environmental monitoring in space and time (Bezerra et al., 2014; Giongo and Vettorazzi, 2014; Silva et al., 2019).

Remote sensing is a technology that allows the collection of information of a region without the need for physical contact. This is possible due to new electronics and computing technologies that have 
taken place in recent decades, especially sensors aboard satellites orbiting the planet that periodically collect images of the terrestrial surface. Satellites have a set of lenses in various electromagnetic wavelengths and visualize every part of the terrestrial surface and between these lenses are some sensors that capture the reflected or emitted surface energy in different bands of the electromagnetic spectrum (Bastiaanssen et al., 1998a; Bastiaanssen et al., 1998b; Bastiaanssen, 2000; Allen et al., 2002; Moreira and Valeriano, 2014).

Based on satellite images and digital processing of these products, it becomes possible to develop some analyzes and estimate micrometeorological biophysical parameters, highlighting vegetation indices, which help in understanding the spatial dynamics of the Brazilian semiarid terrestrial surface. Studies carried out in various regions of the semiarid region stand out as important for dealing with more objective information about reality and can help in management and decision making for the sustainable and efficient use of water and natural resources in semiarid regions (Bezerra et al., 2014; Giongo and Vettorazzi, 2014; Lins et al., 2017; Silva et al., 2019).

Some indices can be applied to observe Caatinga natural vegetation in the semiarid region, highlighting the patterns of vegetation coverage changes in the different soil uses both spatially and temporally as, for example, Normalized Difference Vegetation Index (NDVI) (Silva and Galvíncio, 2012; Oliveira et al., 2017). In addition to analyzing vegetation, also exist indices that highlight the water condition using the principles of the radiation interaction with water as in the case of the Normalized Difference Water Index (NDWI). This parameter which allows a complete spatial-temporal modeling of water issues of surface, essential for planning and management in decision making on the multiple uses of the semiarid, especially when regions present drought events. Studies have used these indices for understanding different types of coverage, as Brito et al. (2017) analyzed the differences of the NDVI and NDWI in preserved and degraded Caatinga areas, as well as areas with irrigated and rainfed agriculture. In turn, Anjos et al. (2017) used the NDWI to compare the reduction of a reservoir in semiarid region of Paraiba.

NDWI, more broadly, has been highlighted in the spatial-temporal monitoring of vegetation, emphasizing that it is highly correlated with water content in vegetation coverage, being important in the studies on plant water stress and effective in the monitoring reservoir water availability (McFeeters, 1996; Xu, 2006).

In this context, aiming to improve the use of practical and efficient technologies to meet recurring needs such as sustainable use of the water resources in the semiarid, the objective of this study was to monitor and quantify the Caatinga vegetation coverage and especially the water availability of the reservoirs, rivers and lakes by means of spatialtemporal modeling of the Modification of Normalized Difference Water Index (MNDWI), using remote sensing techniques and satellite images in the Brazilian semiarid, the period 2015 to 2019.

\section{Materials and methods}

The area of the present study is the municipality of Serra Talhada, belonging to the state of Pernambuco, Northeast Region of the Brazil. The region is located between the parallels of $7^{\circ} 47^{\prime}$ 40.42" S (UTM: $9138406 \mathrm{~m}$ ) and $8^{\circ} 30^{\prime} 42.20^{\prime \prime} \mathrm{S}$ (UTM: $9058941 \mathrm{~m}$ ), and between the meridians of $37^{\circ} 50^{\prime} 54.41 " \mathrm{~W}$ (UTM: $626745 \mathrm{~m}$ ) and $38^{\circ} 45^{\prime}$ 36.26" W (UTM: $526453 \mathrm{~m}$ ), altitude of $444 \mathrm{~m}$, west of the Greenwich meridian. The municipality it's inserted more specifically in the mesoregion of Sertão Pernambucano and in the microregion of Sertão do Pajeú, Brazilian semiarid. According with the 2018 census of the Brazilian Institute of Geography and Statistics (IBGE, 2018), the municipality has 85,774 inhabitants. According to the Köppen climate classification (1936), the region's climate is classified as BSw'h' (semiarid, hot and dry). The average annual rainfall is $656 \mathrm{~mm}$ (33-year climatological data between 1986 and 2018) (ANA, 2019), distributed between the months of winter and deficit in the summer months. The average annual temperature ranges of 22 to $26^{\circ} \mathrm{C}$ (Alvares et al., 2013).

Still, Serra Talhada-PE has an absolute territorial area of $2,980.007 \mathrm{~km}^{2}$ with predominant vegetation and basically composed of Hyperxerophilous Caatinga with excerpts of deciduous forest (Beltrão et al., 2005; IBGE, 2019).

Figure 1 illustrates the study area by means of an image of the Landsat- 8 satellite, Operational Land Imager (OLI) sensor dated 29/11/2018 with spatial resolution of $30 \mathrm{~m}$, in RGB composition, false color infrared with at multispectral bands: 7, 5 and 3 . Also noteworthy is the weather station of the National Water Agency (ANA). 


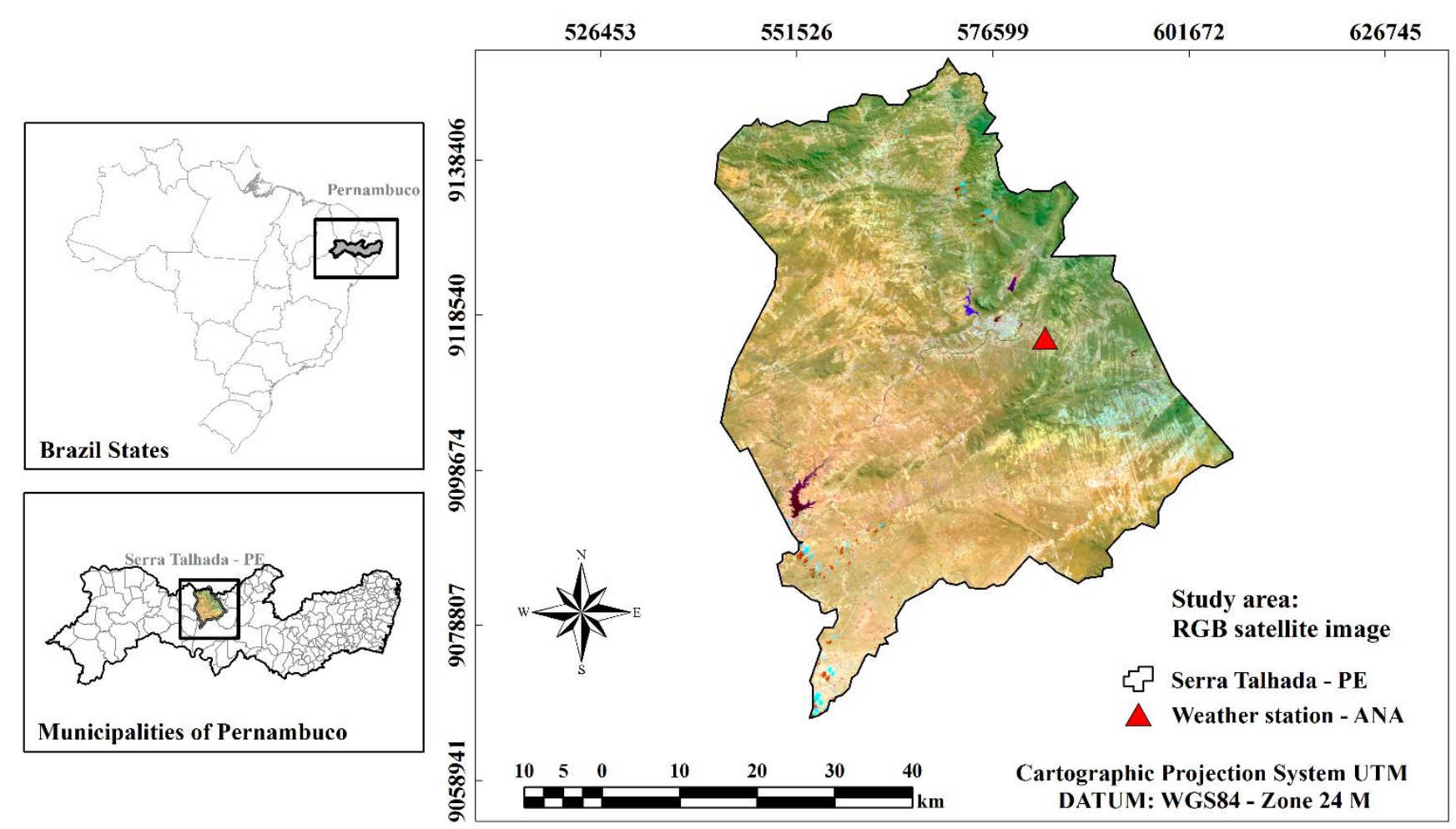

Figure 1 - Spatial map of location of the municipality of Serra Talhada, Pernambuco, Brazil.

Rainfall data were recorded at the ANA weather station (code: 00838031), located in the study area itself at the following geographical coordinates of $8^{\circ} 0^{\prime} 2.16^{\prime \prime} \mathrm{S}$ (UTM: $9115559 \mathrm{~m}$ ) and $38^{\circ} 14^{\prime} 40.92 " \mathrm{~W}$ (UTM: $583236 \mathrm{~m}$ ), and elevation of $435 \mathrm{~m}$. Table 1 presents the monthly total annual rainfall records for the years studied.

Table 1 - Monthly total annual rainfall in the semiarid region of Serra Talhada-PE.

\begin{tabular}{ccccc}
\hline \multirow{2}{*}{ Month } & \multicolumn{4}{c}{ Rainfall $(\mathrm{mm})$} \\
\cline { 2 - 5 } & Year 2015 & Year 2016 & Year 2018 & Year 2019 \\
\hline January & 24.8 & 196.0 & 35.1 & 14.1 \\
February & 77.9 & 22.8 & 192.8 & 101.6 \\
March & 130.0 & 170.8 & 132.3 & 146.5 \\
April & 75.0 & 6.4 & 149.6 & 140.0 \\
May & 64.3 & 33.8 & 0.0 & 46.6 \\
June & 23.2 & 10.2 & 18.8 & 48.2 \\
July & 56.5 & 0.0 & 3.0 & - \\
August & 3.8 & 0.0 & 0.0 & - \\
September & 0.0 & 7.5 & 0.0 & - \\
October & 0.0 & 0.0 & 5.3 & - \\
November & 0.0 & 0.0 & 127.0 & - \\
December & 33.0 & 25.6 & 81.3 & - \\
\hline Total (mm) & 488.5 & 473.1 & 745.2 & 497.0 \\
\hline
\end{tabular}

Figure 2 shows the spatial map of coverage and soil use of the semiarid region of Serra Talhada$\mathrm{PE}$ in 2016. The region belongs entirely to the Caatinga biome, located in the northeast region of Brazil. The map was processed using data of thematic classifications of the Brazilian Annual Land Use and Land Cover Mapping Project (MapBiomas).

The research was realized out using six images of the Landsat- 8 satellite OLI sensor, orbit 216 and $65 / 66$ points, with spatial resolution of $30 \mathrm{~m}$, dated in $04 / 27 / 2015 ; 11 / 21 / 2015 ; 05 / 15 / 2016$; $11 / 23 / 2016,11 / 29 / 2018$ e 04/22/2019. Satellite images were acquired in NASA/USGS (National Aeronautics and Space Administration/United States Geological Survey) platform spatial database. Image processing using multispectral bands was developed using ERDAS IMAGINE® 9.1 software, using steps of the Surface Energy Balance Algorithms for Land (SEBAL) (Bastiaanssen et al., 1998a; Bastiaanssen et al., 1998b; Bastiaanssen, 2000; Allen et al., 2002). 


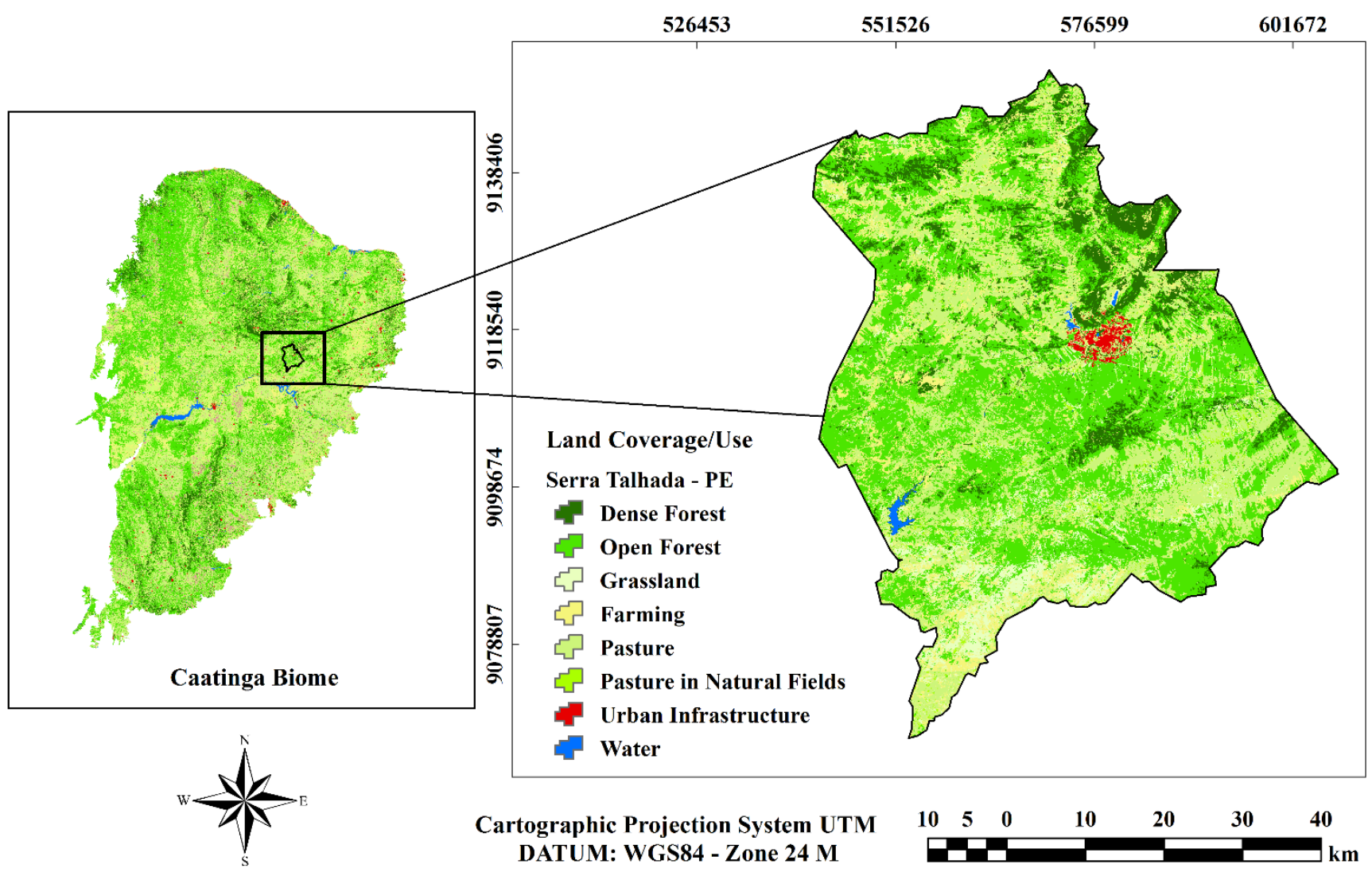

Figure 2 - Spatial map of coverage and soil use in the municipality of Serra Talhada, Pernambuco, Brazil.

They were initially performed processes such as stacking multispectral bands and georeferencing of the study area in the System Cartographic Projection UTM (Universal Transversa Mercator) DATUM: WGS1984 - Zone 24 M. Table 2 shows the Landsat-8 OLI satellite images date and passing time for each day of the year and information of images such as, the square of the ratio between average and instantaneous distances between Earth and Sun (dr) on a given day of the year of image and the solar zenith angle $(\theta)$. The main criterion of choice were images of the dry and rainy season, with condition the clear skies and the largest absence of clouds possible. Its presence overestimates and/or underestimates the values of the micrometeorological biophysical parameters.

Table 2. Image information at the moment of satellite passage in the semiarid region of Serra Talhada-PE.

\begin{tabular}{ccccc}
\hline Satellite & Date of Images & Passing time & $\mathrm{d}_{\mathrm{r}}$ & $\theta$ \\
\hline & $04 / 27 / 2015$ & 09h40min & 0.98 & 0.82 \\
& $11 / 21 / 2015$ & 09h41min & 1.02 & 0.89 \\
Landsat-8 & $05 / 15 / 2016$ & 09h40min & 0.97 & 0.79 \\
OLI Sensor & $11 / 23 / 2016$ & 09h41min & 1.02 & 0.89 \\
& $11 / 29 / 2018$ & 09h41min & 1.02 & 0.88 \\
& $04 / 22 / 2019$ & 09h40min & 0.98 & 0.83 \\
\hline
\end{tabular}

SEBAL highlights the iterative numerical process, with the application of mathematical operations for the spatial-temporal modeling of micrometeorological biophysical parameters (Bastiaanssen et al., 1998a; Bastiaanssen et al., 1998b; Bastiaanssen, 2000; Allen et al., 2002), such as was developed in the present study the Normalized Difference Water Index (NDWI). The NDWI was proposed by McFeeters (1996) and modified by $\mathrm{Xu}$
(2006), called the MNDWI, developed through the reflective bands of the Landsat- 8 satellite images of the OLI sensor.

In the algorithm, the gray levels of all multispectral bands of the images were converted to spectral radiance and monochromatic reflectance through complementing calibration radiometric coefficients. These are Landsat- 8 coefficients specific to the OLI sensor provided by NASA/USGS. These 
procedures are widely used in studies conducted especially in the Brazilian semiarid. (Silva et al., 2016; Lins et al., 2017; Oliveira et al., 2017).

The gray levels of each of the Landsat- 8 reflective bands of the OLI sensor were converted to spectral radiance according to Equation 1 (Chander et al., 2009; Silva et al., 2016).

$$
\mathrm{L}_{\mathrm{b}}=\mathrm{Add}_{\mathrm{rad}}+\text { Mult }_{\mathrm{rad}} \times \mathrm{ND}_{\mathrm{b}}
$$

On what, $\mathrm{L}_{\mathrm{b}}$ - spectral radiance $\left(\mathrm{W} \mathrm{m}^{-2} \mathrm{sr}^{-1} \mu \mathrm{m}^{-1}\right)$ in each band of the image, based on the additive $\left(\mathrm{Add}_{\mathrm{rad}}\right)$ and multiplicative $\left(\mathrm{Mul}_{\text {trad }}\right)$ terms of radiance (NASA/USGS); b (subscribed) represents each of the bands of the satellite image; ND - pixel intensity (digital number between 0 and 65,535 gray levels).

In front of each of the multispectral bands amid their calibration coefficients, the Landsat-8 monochrome reflectance of the OLI sensor was determined according to Equation 2 (Chander et al., 2009; Silva et al., 2016).

$$
r_{b}=\frac{\left(\operatorname{Add}_{\text {ref }}+\text { Mult }_{\text {ref }} \times \mathrm{ND}_{\mathrm{b}}\right)}{\cos \theta \times \mathrm{d}_{\mathrm{r}}}
$$

On what, $\mathrm{r}_{\mathrm{b}}$ - monochrome reflectance $\left(\mathrm{W} \mathrm{m}^{-2} \mathrm{sr}^{-1}\right.$ $\mu \mathrm{m}^{-1}$ ) in each multispectral band of images, based on the additive ( $\left(\mathrm{Add}_{\mathrm{ref}}\right)$ and multiplicative (Mult $\left.\mathrm{ref}_{\mathrm{r}}\right)$ terms of reflectance (NASA/USGS); $\theta$ - solar zenith angle; $d_{r}$ - squared of the ratio between the average and instantaneous distances between the earth and the sun on a given day of the year of image, this was obtained according to Equation 3 (Iqbal, 1983).

$$
\mathrm{d}_{\mathrm{r}}=1+0.033 \times \cos \left(\frac{\mathrm{SDY} \times 2 \times \pi}{365}\right)
$$

On what, SDY - sequential day of the year and the cos function argument is in radians. The average annual value of $\mathrm{d}_{\mathrm{r}}$ is generally 1.00 , varying approximately between 0.97 and 1.03 .

The solar zenith angle ( $\theta$, dimensionless) was obtained through of the sun elevation angle (E, degrees), extracted of the image metadata, according to Equation 4.

$$
\theta=\cos \left(\frac{\pi}{2}-E\right)=\operatorname{sen}(E)
$$

The MNDWI index was modified by the replacing the near infrared band (NIR, Landsat-8 OLI band 5) by the medium infrared band (MIR, Landsat8 OLI band 6). MNDWI varies between -1 and 1 . It is an index that tends to improve open water resources, with more accurate characteristics and positive values greater than NDWI in its normal form, Equation 5 (Xu, 2006).

$$
\text { MNDWI }=\frac{r_{b \text { V }}-r_{b \text { MIR }}}{r_{b \text { V }}+r_{b \text { MIR }}}
$$

On what, $\mathrm{r}_{\mathrm{b}} \mathrm{v}-$ reflective band of green (band 3 OLI sensor) and $\mathrm{r}_{\mathrm{b} \text { MIR }}-$ medium infrared reflective band (OLI sensor band 6). MNDWI $\geq 0$ areas with the presence of water); MNDWI $\leq 0$ (areas with the absence of water in the terrestrial surface; the soil reflects more light of the MIR than of the NIR, and areas with vegetation reflect even more light of the MIR than green light).

\section{Results and discussion}

The spatial-temporal monitoring of the Caatinga vegetation coverage and the water condition of rivers and reservoirs originated land surface response patterns in the municipality of Serra Talhada-PE from thematic maps, which in turn made it possible to highlight soil use changes in the semiarid region, between the period 2015 and 2019 .

Figure 3 shows thematic maps of the MNDWI. The MNDWI highlights the spatialtemporal distribution of the condition of the Caatinga natural vegetation and especially of the water availability of semiarid region.

The region presents different soil uses and occupations. The thematic maps highlight, due to the spatial-temporal monitoring of Caatinga vegetation and of the water bodies, the areas most affected by drought and also by anthropic actions in the municipality of Serra Talhada-PE (Figure 3).

The MNDWI maps ranged between the values of -0.77 to 0.47 . Negative MNDWI values were observed about exposed soil areas and Caatinga vegetation coverage $(-0.77$ to -0.01$)$. Positive values, which ranged from 0.00 to 0.47 , were found on water bodies and, in open waters of rivers and reservoirs of the semiarid region of study (Figure 3). Thus, highlighting as the main feature of this index the emphasis on water monitoring. 


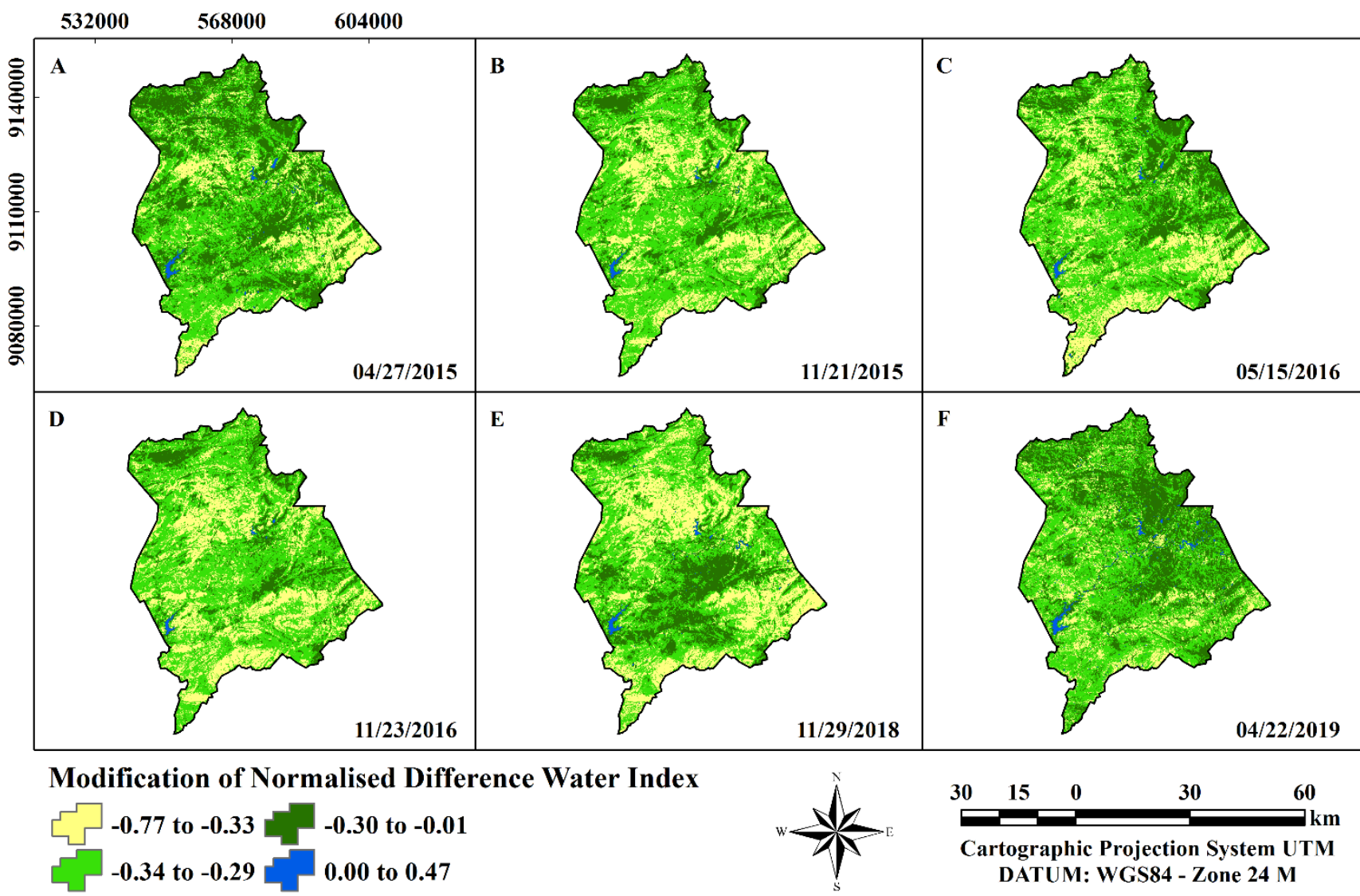

Figure 3 - Spatial-temporal distribution of the Caatinga vegetation coverage and water bodies from the Modification of Normalized Difference Water Index (MNDWI) for the semiarid region of Serra Talhada, Pernambuco, Brazil.

Also, it is noteworthy that the maps showed over time changes in your vegetation coverage of Caatinga, natural condition of this biome in response to rain and/or drought events. However, it is noticeable in some specific points that the exposed soil areas remained in all images, partly justified the biggest confusion between soil and vegetation. However, the presence of exposed soil is more prevalent in dry period images (Figures 3B, 3D and $3 \mathrm{E}$ ), thus becoming a concern due to the increase in deforestation in recent years in semiarid regions, and consequently the acceleration of the serious degradation problems. Bezerra et al. (2014) in a study of the spatial-temporal analysis of vegetation index in the Brazilian semiarid highlighted the relationship of Caatinga vegetation coverage with long periods of drought and anthropic activities, which usually accelerate the processes of environmental degradation.

Remote sensing research monitor and assesses the risk of degradation and desertification in the semiarid over the years. The remote sensing technique characterizes the soil uses through environmental mapping, mainly highlighting the change of vegetation biomass, landscape pattern and micrometeorological conditions. Thus, vegetation indices are essential indicators for detecting changes in semiarid regions. However, the technique aims to mitigate the degrading factors and especially the susceptibility to desertification, being in turn severe drought events together with anthropogenic actions the main factors for the worsening of degradation and desertification in the Brazilian semiarid (Xu et al., 2009; D'Odorico et al., 2013; Gutiérrez et al., 2014; Vorovencii, 2015; Mariano et al., 2018; Silva et al., 2019).

Several studies also about spatial-temporal monitoring and analysis of vegetation indices by remote sensing in the semiarid regions of the Brazil emphasize its reduction due to the Caatinga vegetation coverage in the dry season and, especially, due to the long periods of drought, which are characterized by the fall of the leaves of the forest, which are characterized by the fall of the leaves of the forest, which is a remarkable defense condition of Caatinga itself, due to these times exist a marked water deficit, commonly observed in the semiarid, as well as highlighted in the spatial-temporal distribution behavior of Caatinga in the present study (Rodrigues et al., 2009; Arraes et al., 2012; Bezerra et al., 2014).

On the other hand, other studies in the Brazilian semiarid region also highlighted, due to the rainy season, the increase of vegetation indices due to the increase of rainfall, having Caatinga as a specialty, in the face of these rain events, an 
accelerated resilience power (Rodrigues et al., 2009; Aquino and Oliveira, 2012; Arraes et al., 2012; Bezerra et al., 2014; Ribeiro et al., 2016).

Exactly for this reason, that the images dated in November (Figures 3B, 3D and 3E), referring to the dry period of the region, presented a larger quantity of areas with negative values, corresponding to the exposed soil areas. The years 2015 and 2016 were also dry, due to the most recent drought that began in 2012 and the El Niño recorded in 2015, which may also justify the increase of these exposed soil areas during the study period (Marengo et al., 2018).

Figure 4 shows the quantification of soil use in the Serra Talhada-PE region from the class intervals of the MNDWI thematic maps.

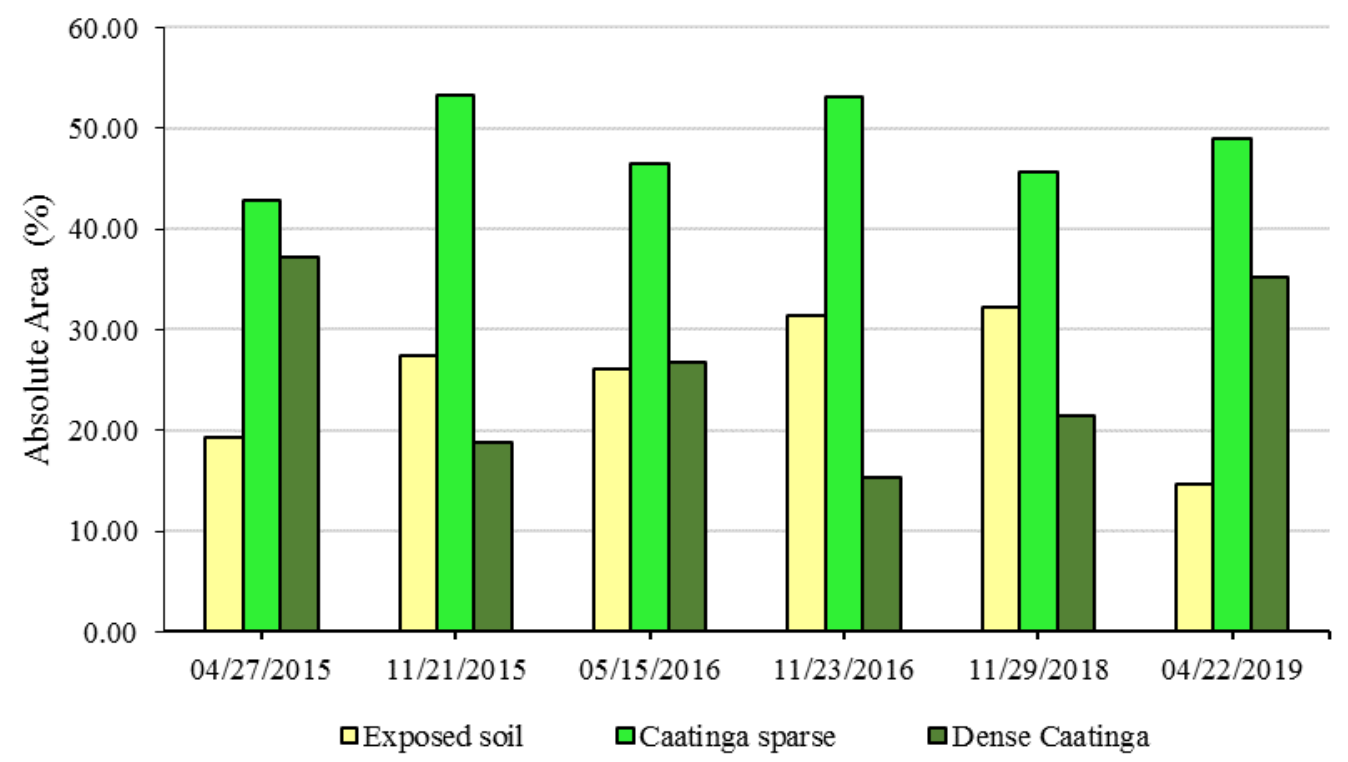

Figure 4 - Quantification of areas of exposed soil, Caatinga sparse and dense of semiarid region, municipality of Serra Talhada-PE.

The quantified areas of exposed soil (yellow) corresponded to the class range of -0.77 to -0.33 from the MNDWI thematic map highlighted previously, and presented percentages for the respective dates of $19.34 \%\left(576.29 \mathrm{~km}^{2}\right) ; 27.43 \%\left(817.08 \mathrm{~km}^{2}\right) ; 26.13 \%$ $\left(778.33 \mathrm{~km}^{2}\right) ; 26.13 \%\left(933.93 \mathrm{~km}^{2}\right) ; 26.13 \%(962.41$ $\left.\mathrm{km}^{2}\right)$ and $26.13 \%\left(435.65 \mathrm{~km}^{2}\right)$ of the total area (Figure 4). It is noteworthy that in these areas are incorporated the pasture areas of the region, because in the dry season they are exposed. In a study conducted also in semiarid region of the Brazil, Aquino and Oliveira (2012) highlighted a reduction in soil exposed areas when observed elevation vegetation index due to the increased rainfall.

It is also worth mentioning, this fact may be related to the confusion in the spectral response of the soil and vegetation during the dry season, thus in these conditions the vegetation can be classified as soil. In this sense, the map of coverage and soil use was developed through thematic classification of MapBiomas for the semiarid region under study in order to better clarification of the region (Figure 2).

Also noteworthy is the quantification of areas with natural vegetation coverage of Caatinga sparse (light green), which corresponded to the class interval of -0.34 to -0.29 of the MNDWI map, with percentages for the respective dates of $42.75 \%$ $\left(1273,59 \mathrm{~km}^{2}\right) ; \quad 53.33 \% \quad\left(1588.62 \mathrm{~km}^{2}\right) ; \quad 46.56 \%$ $\left(1386.89 \mathrm{~km}^{2}\right) ; \quad 53.06 \%\left(1580.70 \mathrm{~km}^{2}\right) ; 45.65 \%$ $\left(1359.81 \mathrm{~km}^{2}\right)$ and $48.96 \%\left(1458.53 \mathrm{~km}^{2}\right)$ of the total area (Figure 4). It is noteworthy that the areas of Caatinga sparse were highlighted with greater intensity in the thematic maps in all days of analysis, showing with the highest percentages of total area of the municipality of Serra Talhada-PE. This behavior remained in the rainy season so as to dry (Figure 3 ).

The quantification of areas with natural vegetation coverage of dense Caatinga (dark green) corresponded to the class interval of -0.30 to -0.01 of the MNDWI map, with percentages for the respective dates of $37.17 \%\left(1107.36 \mathrm{~km}^{2}\right) ; 18.88 \%(562.34$ $\left.\mathrm{km}^{2}\right) ; 26.80 \%\left(798.53 \mathrm{~km}^{2}\right) ; 15.36 \%\left(457.51 \mathrm{~km}^{2}\right)$; $21.45 \%\left(638.87 \mathrm{~km}^{2}\right)$ and $35.19 \%\left(1048.24 \mathrm{~km}^{2}\right)$ of the total area (Figure 4). The dense Caatinga has been preserved in some specific points of the thematic maps, however, the region needs more attention and constant monitoring aiming the planning and management of the soil uses (Figure 3).

Figure 5 highlights the thematic maps of the MNDWI with emphasis for the water bodies of the semiarid region. The spatial-temporal distribution of water availability highlights among the maps the behavior of rivers and reservoirs, essential for the multiple uses of Serra Talhada-PE. 


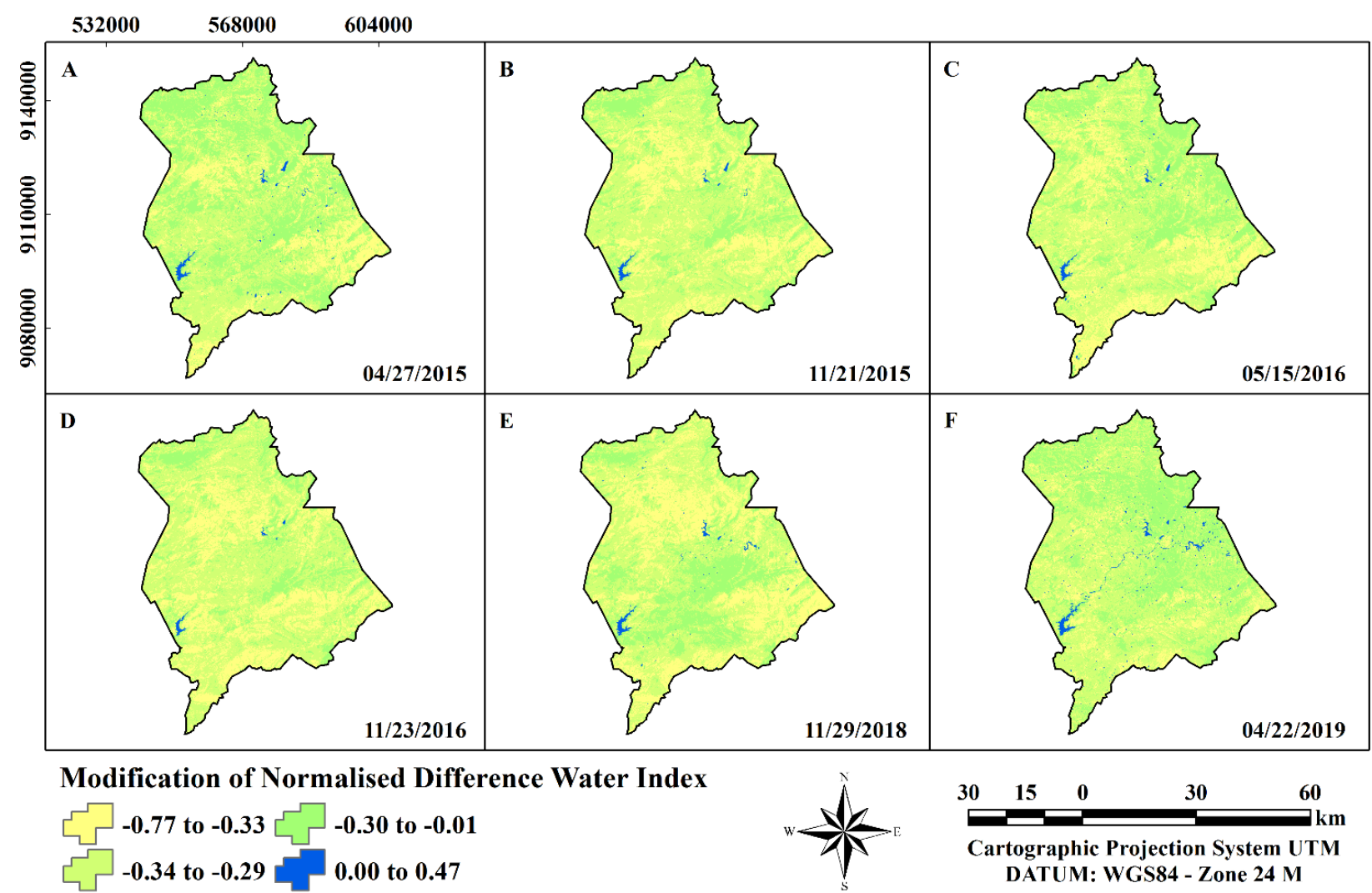

Figure 5 - Spatial-temporal distribution of water availability from the Modification of Normalized Difference Water Index (MNDWI) for the semiarid region of Serra Talhada, Pernambuco, Brazil.

Thematic maps show the water condition of the rivers and reservoirs (blue pixels), this type of environmental monitoring allowed highlighting the main water bodies and the response pattern of these in relation to the dry periods. The water bodies are located mainly on the areas to the southwest and also on the areas northeast of thematic maps (Figure 5).

Water availability illustrated in the maps ranged from 0.00 to 0.47 . The map of $11 / 23 / 2016$ (Figure 5D) presents the most critical level in the spatial-temporal analysis. On the other hand, the map of the day 04/22/2019 (Figure 5F) deserves to be highlighted because it has greater water availability in the region, including river courses. The thematic map of coverage and soil use in the semiarid region under study, developed through thematic classification of MapBiomas, represented and confirmed the water bodies of the region efficiently (Figure 2).

Figure 6 also shows the quantification of water availability of the semiarid region of Serra Talhada-PE according to the class intervals of the MNDWI thematic maps highlighted previously.

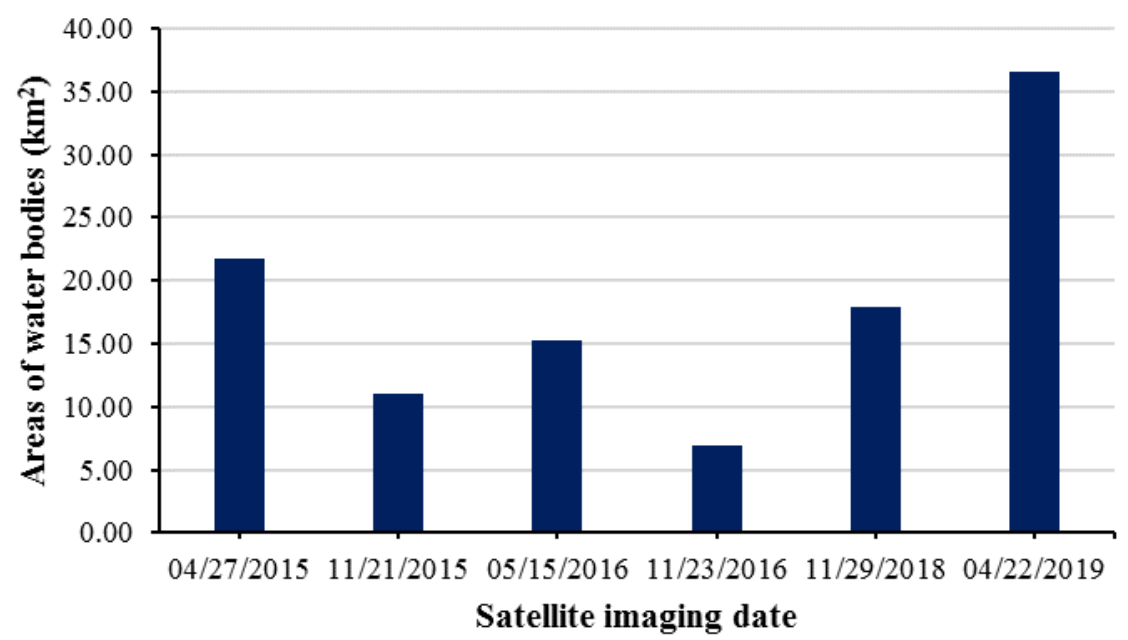

Figure 6 - Quantification of the areas of water bodies of the semiarid region, municipality of Serra Talhada-PE. 
The quantification of areas covered by water bodies corresponded to the class interval of 0.00 to 0.47 of the MNDWI map with emphasis to the water (Figure 5). The maps presented percentages for the respective dates of $21.79 \mathrm{~km}^{2}(0.73 \%) ; 10.98 \mathrm{~km}^{2}$ $(0.37 \%) ; 15.28 \mathrm{~km}^{2}(0.51 \%) ; 6.89 \mathrm{~km}^{2}(0.23 \%)$; $17.93 \mathrm{~km}^{2}(0.60 \%)$ and $36.61 \mathrm{~km}^{2}(1.23 \%)$ of the total area (Figure 6). Zhang et al. (2016) emphasized the high capacity of remote sensing techniques in the spatial-temporal monitoring of water availability and related ecosystem responses both in the face of climate change, as well as to conflicts arising from anthropic actions.

The day 11/23/2016 had the lowest representation of water condition among the other satellite passing days, although the days of previous years were relatively low due to the long period of drought in the semiarid. The regions of the Brazilian semiarid, especially between 2012 and 2016, faced severe drought events, reflecting on water scarcity and low reservoir volumes, gradually compromising multiple uses and also evidencing significant losses in irrigated agriculture (Gutiérrez et al., 2014; Marengo et al., 2016; Barbosa et al., 2018; Marengo et al., 2018). Images within this period, for example, in the 2015 and 2016 had rainfall below the historical annual average $(656 \mathrm{~mm})$, with values of 488.5 and $473.1 \mathrm{~mm}$ (Table 1), respectively. The low rainfall corroborates the low levels of the reservoirs, the little activity of the Caatinga vegetation and consequently the increase of exposed soil areas.

On the other hand, 04/22/2019 it is highlighted for the higher water availability observed in the spatiotemporal analysis of the semiarid region. The year 2018 it is highlighted for presenting higher rainfall rates, in a total annual average of $745.2 \mathrm{~mm}$ (Table 1), above the historical average $(656 \mathrm{~mm})$ of the region, which directly favored the greater water availability and greater distribution of soil moisture, consequently greater vigor of the natural vegetation of Caatinga due to its resilience, as well as greater water availability in the reservoirs, which contributed to the year 2019, which also started with favorable rains and it is highlighted with the flooding of the region rivers and reservoirs (Figure 5). It is noteworthy that the image of the year 2019 was captured in the rainy season.

The quantification and characterization of Caatinga vegetation coverage and water bodies will serve to understand and compare research on environmental impact assessment. Studies and applications of vegetation indices in the Brazilian semiarid are extremely important to differentiate spectral information of the vegetation and other specific elements in the terrestrial surface. Vegetation indices can determine and indicate the quality and quantity of vegetation coverage in semiarid regions, both in the rainy season and in the dry season (Ribeiro et al., 2016; Lins et al., 2017).

\section{Conclusions}

The spatial-temporal monitoring of the vegetation index of Modification of Normalized Difference Water Index demonstrated, through thematic maps of the terrestrial surface, the response patterns and conditions of degrading changes of the Caatinga vegetation coverage, as well as the water availability of semiarid region of the municipality of Serra Talhada-PE.

Drought favored water scarcity among spatial-temporal analysis, highlighting a marked water deficit and low levels of the reservoir of semiarid region, which possibly, directly affected the multiple uses of the municipality of Serra TalhadaPE.

Remote sensing is a strong ally for the studies of the water and natural resources in semiarid regions of the Brazil, especially when the absence of surface environmental data is common, making it impossible highlight the changing conditions and vulnerabilities of the Caatinga biome and reservoirs in these regions, especially during drought events, thus becoming a highly applicable tool in the largescale environmental mapping.

However, from this type of environmental monitoring, it is expected to mitigate the processes of water degradation and collapse, for that there is no loss mainly in the region's agriculture, especially when the periods of drought are evident, when at local socioeconomic conditions tend to be critical in the Brazilian semiarid.

\section{Acknowledgments}

The Federal Rural University of Pernambuco; Postgraduate Program in Agricultural Engineering; This study was financed in part by the Coordenação de Aperfeiçoamento de Pessoal de Nível Superior Brasil (CAPES) - Finance Code 001; NASA/USGS for providing satellite images and National Water Agency (ANA) for providing rainfall data. Also to MapBiomas for providing thematic classifications of coverage and soil use.

\section{References}

Allen, R., Tasumi, M., Trezza, R., Waters, R., Bastiaanssen, W., 2002. SEBAL: Surface Energy Balance Algorithms for Land, Idaho implementation. Waters Consulting, University of 
Idaho, Idaho. (Advanced Training and Users Manual, Version 1.0).

Alvares, C.A., Stape, J.L., Sentelhas, P.C., MORAES, G., Leonardo, J., Sparovek, G., 2013. Köppen's climate classification map for Brazil. Meteorologische Zeitschrift 22, 711-728.

ANA. Agência Nacional de Águas, 2019. Portal HidroWeb: Acervo de dados hidrológicos. Séries Históricas de Estações (1986-2017). Disponível: http://www.snirh.gov.br/hidroweb/publico/medico es_historicas_abas.jsf. Acesso: 10 jun. 2019.

Anjos, D.M., Soares, D.D.M.A., Simões, E.M., Leite, A.C.C.P., Ramos, T.M., Bakke, I.A., 2017. Temporal analysis of water volume at Capoeira Reservoir Mãe d'Água, Paraíba, Brazil. Revista Verde de Agroecologia e Desenvolvimento Sustentável 12, 138-142.

Aquino, C.M.S., Oliveira, J.G.B., 2012. Estudo da dinâmica do índice de vegetação por diferença normalizada (NDVI) no núcleo de São Raimundo Nonato-PI. GEOUSP: Espaço e Tempo (Online) 31, 157-168.

Araujo, J.C., Güntner, A., Bronstert, A., 2006. Loss of reservoir volume by sediment deposition and its impact on water availability in semiarid Brazil. Hydrological Sciences Journal 51, 157-170.

Arraes, F.D.D., Andrade, E.M., Silva, B.B., 2012. Dinâmica do balanço de energia sobre o açude Orós e suas adjacências. Revista Caatinga 25, 119-127.

Barbosa, H.A., Lakshmi Kumar, T., Paredes, F., Elliott, S., Ayuga, J.G., 2018. Assessment of Caatinga response to drought using MeteosatSEVIRI Normalized Difference Vegetation Index (2008-2016). ISPRS Journal of Photogrammetry and Remote Sensing 148, 235-252.

Bastiaanssen, W.G.M., 2000. SEBAL - Based Sensible and Latent Heat Fluxes in the Irrigated Gediz Basin, Turkey. Journal of Hydrology 229, 87-100.

Bastiaanssen, W.G.M., Pelgrum, H., Wang, J., MA, Y., Moreno, J.F., Roerink, G.J., Van Der Wal, T., 1998a. A remote sensing surface energy balance algorithm for land (SEBAL) 1. Formulation. Journal of Hydrology 212-213, 198-212.

Bastiaanssen, W.G.M., Menenti, M., Feddes, R.A., Holtslag, A.A.M., 1998b. A remote sensing surface energy balance algorithm for land (SEBAL) 2. Validation. Journal of Hydrology 212-213, 213-229.

Beltrão, B.A., Mascarenhas, J.C., Miranda, J.L.F., Souza Junior, L.C., Galvão, M.J.T.G., Pereira, S.N., 2005. Projeto Cadastro de Fontes de Abastecimento por Água Subterrânea. Diagnóstico do município de Serra Talhada, Estado de Pernambuco. CPRM/ PRODEEM, Recife.
Bezerra, J.M., Moura, G.B.A., Silva, B.B., Lopes, P.M.O., Silva, E.F.F., 2014. Parâmetros biofísicos obtidos por sensoriamento remoto em região semiárida do estado do Rio Grande do Norte, Brasil1. Revista Brasileira de Engenharia Agrícola e Ambiental 18, 73-84.

Brito, P.V.S., Morais, Y.C.B., Ferreira, H.S., Silva, J.F., Galvíncio, J.D., 2017. Análise comparativa da umidade da vegetação de áreas de Caatinga preservada, agricultura irrigada e sequeiro. Journal of Environmental Analysis and Progress 2, 493-498.

Chander, G., Markham, B.L.; Helder, D.L., 2009. Summary of current radiometric calibration coefficients for Landsat MSS, TM, ETM+, and EO-1 ALI sensors. Remote Sensing of Environment 113, 893-903.

D’Odorico, P., Bhattachan, A., Davis, K.F., Ravi, S., Runyan, C.W., 2013. Global desertification: drivers and feedbacks. Advances in Water Resources 51, 326-344.

Giongo, P.R., Vettorazzi, C.A., 2014. Albedo da superfície por meio de imagens TM-Landsat 5 e modelo numérico do terreno. Revista Brasileira de Engenharia Agrícola e Ambiental 18, 833-838.

Gutiérrez, A.P.A., Engle, N.L., De Nys, E., Molejón, C., Martins, E.S., 2014. Drought preparedness in Brazil. Weather and Climate Extremes 3, 95-106.

IBGE. Instituto Brasileiro de Geografia e Estatística, 2018. População estimada: IBGE, Diretoria de Pesquisas, Coordenação de População e Indicadores Sociais, Estimativas da população residente com data de referência a julho de 2018. Disponível:

https://cidades.ibge.gov.br/brasil/pe/serratalhada/panorama. Acesso: 10 jun. 2019.

IBGE., 2019. Instituto Brasileiro de Geografia e Estatística. Área da unidade territorial: Área territorial brasileira. IBGE, Rio de Janeiro. Disponível:

https://cidades.ibge.gov.br/brasil/pe/serratalhada/panorama. Acesso: 10 jun. 2019.

Iqbal, M., 1983. An Introduction to Solar Radiation. Academic Press., London.

Köppen, W., 1936. Das geographische System der Klimate. Köppen, in: Geiger, W.R. (Ed.), Handbuch der Klimatologie. Gebrüder Bornträger 1, 1-44, part C.

Lins, F.A.C., Araújo, D.C.S., Silva, J.L.B., Lopes, P.M.O., Oliveira, J.D.A., Silva, A.T.C.S.G., 2017. Estimativa de parâmetros biofísicos e evapotranspiração real no semiárido Pernambucano utilizando sensoriamento remoto. Irriga 1, 64-75.

MAPBIOMAS. Projeto de Mapeamento Anual da Cobertura e Uso do Solo no Brasil, 2019. Classificação temática do Bioma Caatinga. 
Disponível:

http://mapbiomas.org/pages/database/mapbiomas_ collection. Acesso: 13 out. 2019.

Marengo, J.A., Alves, L.M., Alvala, R., Cunha, A.P., Brito, S., Moraes, O.L., 2018. Climatic characteristics of the 2010-2016 drought in the semiarid Northeast Brazil region. Anais da Academia Brasileira de Ciências 90, 1973-1985.

Marengo, J.A., Torres, R.R., Alves, L.M., 2016. Drought in Northeast Brazil-past, present, and future. Theoretical and Applied Climatology 129, 1189-1200.

Mariano, D.A., Santos, C.A., Wardlow, B.D., Anderson, M.C., Schiltmeyer, A.V., Tadesse, T., Svoboda, M.D., 2018. Use of remote sensing indicators to assess effects of drought and humaninduced land degradation on ecosystem health in Northeastern Brazil. Remote Sensing of Environment 213, 129-143.

McFeeters, S.K., 1996. The use of normalized difference water index (NDWI) in the delineation of open water features. International Journal of Remote Sensing 17, 1425-1432.

Medeiros, L.C., Guedes, J.C.F., Oliveira, A.M., Costa, D.F.S., 2016. Uso de SIG na análise dos recursos hídricos no município de Caicó (RN). Geoambiente On-line 27, 134-149.

Moreira, E.P., Valeriano, M.M., 2014. Application and evaluation of topographic correction methods to improve land cover mapping using object-based classification. International Journal of Applied Earth Observations and Geoinformation 32, 208217.

Oliveira, J.D.A., Medeiros, B.C., Silva, J.L.B., Moura, G.B.A., Lins, F.A.C., Nascimento, C.R., Lopes, P.M.O., 2017. Space-temporal evaluation of biophysical parameters in the High Ipanema watershed by remote sensing. Journal of Hyperspectral Remote Sensing 7, 357-366.

Ribeiro, E.P., Nóbrega, R.S., Mota Filho, F.O., Moreira, E.B., 2016. Estimativa dos índices de vegetação na detecção de mudanças ambientais na bacia hidrográfica do rio Pajeú. Geosul 31, 59-92.

Rodrigues, J.D., Andrade, E.D., Teixeira, A.D.S., Silva, B.D., 2009. Sazonalidade de variáveis biofísicas em regiões semiáridas pelo emprego do sensoriamento remoto. Engenharia Agrícola 29, 452-465.

Silva, B.B.D., Braga, A.C., Braga, C.C., Oliveira, L.M., Montenegro, S.M., Barbosa Junior, B., 2016. Procedures for calculation of the albedo with OLI-Landsat 8 images: Application to the Brazilian semi-arid. Revista Brasileira de Engenharia Agrícola e Ambiental 20, 3-8.

Silva, D.A.O., Lopes, P.M.O., Moura, G.B.A., França e Silva, E.F., Silva, J.L.B., Bezerra, A.C., 2019. Evolução Espaço-Temporal do Risco de Degradação da Cobertura Vegetal de PetrolinaPE. Revista Brasileira de Meteorologia 34, 1-11.

Silva, L.G., Galvíncio, J.D., 2012. Análise comparativa da variação nos índices NDVI e SAVI no Sítio PELD - 22, em Petrolina - PE, na primeira década do século XXI. Revista Brasileira de Geografia Física 5, 1446-1456.

Vorovencii, I., 2015. Assessing and monitoring the risk of desertification in Dobrogea, Romania, using Landsat data and decision tree classifier. Environmental monitoring and assessment 187204.

Xu, D., Kang, X., Qiu, D., Zhuang, D., Pan, J., 2009. Quantitative Assessment of Desertification Using Landsat Data on a Regional Scale - A Case Study in the Ordos Plateau, China. Sensors 9, 17381753.

Xu, H., 2006. Modification of normalised difference water index (NDWI) to enhance open water features in remotely sensed imagery. International Journal of Remote Sensing 27, 3025-3033.

Zhang, K., Kimball, J.S., Running, S.W., 2016. A review of remote sensing based actual evapotranspiration estimation. Wiley Interdisciplinary Reviews: Water 3, 834-853. 